Part I:

Constitutional Review and Judicial Independence 



\title{
The Appointment of the Members of the Algerian Constitutional Council
}

\author{
Wissam Benyettou
}

\begin{abstract}
Algeria has introduced a constitutional council only a few years after France has done so in its Fifth Republic. Still, it has come to life as a permanent institution for constitutional review in 1989. Although being inspired by the French model, the Algerian Constitutional Council has increasingly parted from this model. By giving an account of the composition of the Constitutional Council and the appointment process through the past decades, the chapter discerns the Council's nature and weakness as being more of a political character than a judicial one. This is identified as a general reflex of the weak separation of powers to the benefit of the executive. Comparing with other countries in the region that have also been inspired by the French model, the author recommends to follow the direction of Morocco and Tunisia, which have moved away from the political-judicial composition and mandate (French). ${ }^{1}$
\end{abstract}

\section{Introduction}

Algeria has a constitutional council since its independence; thanks to its first constitution adopted by referendum in 1963. Established as a politicojudicial institution, it was inspired by the French Constitutional Council that was created five years earlier by the constitution of the Fifth Republic. Since the creation of this model, more than a dozen countries around the world have decided to adopt this type of institution, among them four Arab countries alongside Algeria (Morocco, Mauritania, Tunisia, and Lebanon).

Although the idea originated in France, the Algerian Constitutional Council stands out from the French model by certain elements. The appointment of the members of the Council is among the most salient

1 This chapter has been written in 2018 and reflects the situation up to that date. 
points. While in France two constitutional "powers" appoint the members of the Constitutional Council, namely the legislature and the executive, in Algeria the choice was to also include the judiciary. The French idea of excluding the judicial "authority" from the appointment process was not accepted by independent Algeria.

The Algerian Constitution of 1963 opted for a model of the composition of the Constitutional Council giving priority to the judicial and legislative power over the executive power. The Council was composed of three members from the judiciary, three members from the legislature and one member appointed by the President of the Republic. The Council's president was to be elected by its members and explicitly had no preponderant vote (art. 63).

The First Algerian Constitutional Council survived only three years. Thus, following the political overthrow of President Ben Bella in 1965, the 1963 Constitution was suspended. It was not until 1983 that the Single Party Congress (FLN) called for the creation of a constitutional review body.

Finally, the Constitution of 1989 resurrected the Algerian Constitutional Council. The composition was still of seven members but with a majority of three members appointed by the President of the Republic, whereas the members of the judiciary and the legislature are now only two each (art. 154). Here, the first shift towards more influence of the executive power started, with the first democratic Constitution of Algeria. The 1996 Amendment increased membership to nine members, this time giving the majority to Parliament (art. 164). Finally, the 2016 revision established composition of 12 members, giving each constitutional power an equal share of four members to be appointed. The changes in the composition of the Algerian Constitutional Council show how the political system is searching for a specific model that would integrate the judicial component into the original model without jeopardizing the stability of the political regime dominated by the executive.

In this chapter, the issue of the appointment of the members to the Algerian Constitutional Council will be addressed by examining aspects of the composition of the Council through a comparative perspective. It should be kept in mind that the analysis of the Algerian Constitutional Council is at the same time an analysis of an institutional model of French inspiration transposed into a post-colonial country of the Arab region. 


\section{The procedure for the appointment of members of the Constitutional Council}

Since 1963, the Algerian constitutions stipulate that the members of the Constitutional Council should be appointed representing each of the three constitutional powers. Consequently, the members representing the judicial power are judges of the highest courts. Members representing the legislature are members from the two chambers of Parliament. The members representing the executive power are freely chosen by the President of the Republic.

This rule was respected despite the various reforms. The appointment within each power is specific and differs from that applied in France or other Arab countries with constitutional councils. The composition according to the 2016 revision (art. 183) is the following:

- The members representing the judiciary: Four of them are judges elected in the Supreme Court and the State Council (two per court). In other words, they are judges of the two courts elected by their peers. Since 1989 , the practice has been that of internal elections by the judges of each court under the supervision of the respective presidents. Any judge of the Supreme Court and of the Council of State shall have the right to stand as a candidate and to request the voting of his or her pairs.

- The members representing the legislative power: There are four members originating from the legislature, elected within the two chambers. Here also the vote is organized by the presidents of the chamber and the candidatures are open to any MP.

- The members representing the executive power: Four of the members are personalities freely chosen by the President of the Republic. Two of the four members appointed by the President are, by constitutional provision, the resident and vice-president of the Council. They are therefore the most important and influential members of the Council.

This overview of the procedure demonstrates the distance taken from the model of the French Constitutional Council. There, members appointed by the French Parliament do not come from the legislature, but traditionally are judges/lawyers appointed by the presidents of the two parliamentary chambers (The People's National Assembly and Council of the Nation). The difference is that in France the Speaker appoints members to the Council on behalf of Parliament while in Algeria the members of the parliamentary chambers elect among themselves four members to the Council. 
The Algerian Constitutional Council is therefore an institution composed of judges of the highest judicial bodies and members of the legislature elected by their pairs in addition to members freely chosen by the President of the Republic.

One can argue that the result of this method of appointment is to have a politically legitimate and institutionally balanced institution. Despite these appearances of balance of power in the composition of the Constitutional Council, the influence of the executive power is decisive at least on two counts.

First, the President of the Republic appoints the President of the Council. The latter having a casting vote in the event of a tie. He also has wide powers in the internal management of the Council, in particular in terms of calling meetings, appointing the distribution of appeals and cases between members.

The President of the Republic also interferes in the appointment of judges to the Constitutional Council in an indirect way, via the judicial power. It is the Supreme Council of the Judiciary which decides on the appointment of all judges. This body for judicial appointments is chaired by the President of the Republic as a "guarantor of the independence of the judiciary". In other words, judges eligible to become members of the Constitutional Council were first appointed to their function under the supervision of the President and by presidential decree.

\section{Eligibility criteria}

Until the revision of 2016, no conditions were set for personal or academic eligibility criteria. Since then, Article 184 of the Constitution requires that a member of the Constitutional Council must imperatively:

- be 40 years of age or older;

- have at least fifteen (15) years' professional experience in higher education in the legal sciences, the judiciary, the legal profession of the Supreme Court or the Council of State, or function of the State.

These new conditions will certainly reduce the scope of eligible candidates in both chambers of the legislature. Indeed, if in the past these conditions have de facto applied to the judges elected from the high courts and to the majority of the members designated by the President, it did not with regard to the members from the legislature appointed to the Constitutional Council. 
This new criterion of professional experience will undoubtedly reinforce the technical judicial skills of the Constitutional Council.

It is interesting to note that the addition of technical capacity criteria in law follows the trend that prevails in the Arab region and departs from the French model. Indeed, the Tunisian, Moroccan, Libyan, and Yemeni constitutions require qualifications in law or political science for appointment to constitutional courts. France, despite the introduction of the a posteriori control of legislation (question prioritaire de constitutionnalité), continues to require no technical or age criteria for the appointment of members of the Constitutional Council.

The 2016 reform can be expected to strengthen the judicial character of the Council. Political legitimacy stemming from the constitutional powers that designate the members was no longer considered sufficient. Thus, to this indirect democratic legitimacy was added a technical legitimacy.

\section{Profiles of members of the Constitutional Council}

The profile of Council members appointed since 1989 varies according to the institution from which they come. Members elected under the Supreme Court and the Council of State are highly experienced judges who have left the Institute for Judicial Training (ESM) or the National School of Administration (ENA).

Parliamentarians, on the other hand, who for the most part have a purely political career and have little legal expertise. What counts for the election of the members of the Council is partisan affiliation. Indeed, since 1996 the members of the legislature sitting in the Constitutional Council are almost all from the FLN (National Liberation Front) and the RND (National Rally for Democracy). Traditionally the Senators of the Council of the Nations (the Upper House) come from the RND whereas the deputies of the Popular National Assembly (the Lower House) are of the FLN. This division reflects the division of roles between these two parties that has shared power for over 20 years in Algeria. The FLN has always assumed the presidency of the Assembly while the RND presides over the Senate.

The new criteria mentioned above must therefore upset the traditions of the appointment of parliamentarians to the Council. The technical filter imposes itself on the calculations between these two parties.

With regard to the members of the Constitutional Council appointed by the President of the Republic, and given the President's freedom of choice, it is interesting to dwell on the nature of choices made since 1989. 
The Presidents of the Republic appointed 18 members of the Council since 1989. Ten of the designated members were lawyers or judges. The remaining eight were senior officials who have served as ministers or ambassadors, half of which lawyers by training. As a whole, of the members appointed by the President, only two were women.

In the waves of appointments to each new term, it can be noted that in the majority of cases, the President of the Republic appoints trained and career lawyers to around two thirds. The Council by 2017 is an exception, as only two out of four are legal experts (see Fig. 1). Overall, from the members of the Constitutional Council nominated by the President of the Republic, between 1989 and 2017, 56\% were politicians or senior officials, and $44 \%$ judges or jurists.

As for the Presidents of the Council, out of the six that have succeeded this post, by 2017 three were lawyers against three political personalities.

\section{Fig. 1. The members of the Constitutional Council (2017).}

\begin{tabular}{|c|c|c|}
\hline Member & Nominated by & Profile \\
\hline Mourad MEDELCI (President) & President of the Republic & $\begin{array}{l}\text { Economist, FLN Leader and for- } \\
\text { mer Minister of Economy and For- } \\
\text { eign Affairs }\end{array}$ \\
\hline $\begin{array}{l}\text { Mohamed Habchi (Vice Presi- } \\
\text { dent) }\end{array}$ & President of the Republic & $\begin{array}{l}\text { Senior Official, Former Advisor to } \\
\text { the President of the Republic }\end{array}$ \\
\hline $\begin{array}{l}\text { Hanifa BENCHABANE (Mem- } \\
\text { ber) }\end{array}$ & President of the Republic & Jurist, Professor of Private Law \\
\hline Abdeldjalil BELALA (Member) & President of the Republic & $\begin{array}{l}\text { Jurist, Professor of International } \\
\text { Public Law }\end{array}$ \\
\hline Brahim BOUTKHIL (Member) & $\begin{array}{l}\text { Council of Nation (Upper } \\
\text { House) }\end{array}$ & $\begin{array}{l}\text { RND Leader, Member of the Par- } \\
\text { liament }\end{array}$ \\
\hline Hocine DAOUD (Member) & $\begin{array}{l}\text { Council of Nation (Upper } \\
\text { House) }\end{array}$ & $\begin{array}{l}\text { RND Leader, Member of the Par- } \\
\text { liament }\end{array}$ \\
\hline Abdenour GRAOUI (Member) & $\begin{array}{l}\text { Popular National Assem- } \\
\text { bly (Lower House) }\end{array}$ & $\begin{array}{l}\text { FLN Leader, Member of the Parlia- } \\
\text { ment }\end{array}$ \\
\hline Mohamed DIF (Member) & $\begin{array}{l}\text { Popular National Assem- } \\
\text { bly (Lower House) }\end{array}$ & $\begin{array}{l}\text { FLN Leader, Member of the Parlia- } \\
\text { ment }\end{array}$ \\
\hline Ismail BALIT (Member) & Supreme Court & Supreme Court Judge \\
\hline $\begin{array}{l}\text { M. El Hachemi Brahmi (Mem- } \\
\text { ber) }\end{array}$ & Supreme Court & $\begin{array}{l}\text { Judge of the Supreme Court, for- } \\
\text { mer President of the National } \\
\text { Commission for the Supervision of } \\
\text { Elections }\end{array}$ \\
\hline Kamel Fenniche (Member) & $\begin{array}{l}\text { Council of State (Highest } \\
\text { Administrative Court) }\end{array}$ & Judge of the Council of State \\
\hline $\begin{array}{l}\text { Faouzya BENGUELLA (Mem- } \\
\text { ber) }\end{array}$ & $\begin{array}{l}\text { Council of State (Highest } \\
\text { Administrative Court) }\end{array}$ & Judge of the Council of State \\
\hline
\end{tabular}


While the criteria for appointment to the Constitutional Council have been laid down by the various succeeding constitutions, the functioning of the Council is governed by an organic law. It gives a preponderant role to the President of the Council, appointed by the President of the Republic.

\section{Limited term of office}

The members of the Algerian Constitutional Council are appointed for a single term of eight years. They are renewed by half every four years. Their mandate is incompatible with any other professional or political activity. They are subject to the obligation of reserve and impartiality. If a member of the Council ceases to fulfil the conditions required for the performance of his duties or has seriously failed to fulfil his duties, he shall submit his resignation if requested unanimously by the Council.

The Constitutional Council as described by the Constitution is independent and its decisions apply to all. No other authority can challenge its opinions and decisions. As a result, the members of the Board enjoy full independence in the performance of their duties. In 30 years of existence, no cases of resignation have been noted for political pressure. The criteria for eligibility make the Board naturally homogeneous. Dissenting opinions are almost impossible. The opinions and decisions of the Council are signed and proclaimed by unanimity of the members, individual opinions not being a traditional practice of the Constitutional Council.

\section{The impact of the composition of the Constitutional Council on its decision- making process}

The composition of the Constitutional Council derives from the political and judicial powers in place. The selection procedure reflects the political nature of the institution. De facto, two-thirds of the Council (eight members) stem from the political institutions that govern the country. These eight members are appointed by the President-elect of the people and among the deputies elected in the two chambers of the legislature. The nature of the Algerian political system being of semi-presidential type with broad presidential powers, cohabitation in the sense of the President being from a different political party than the majority in Parliament, is very unlikely and has never occurred before. Consequently, the eight members designated by the political authorities are a priori like-minded. 
The remaining four members are judges elected by their peers from among the high courts. As mentioned above, these same judges are appointed by a Supreme Judicial Council chaired by the President of the Republic. Even if it is legitimate to describe its members as worthy representatives of the judiciary, it must be noted that the influence of the executive power remains.

The engineering of the composition of the Constitutional Council is therefore made so that political allegiance is paramount. The duty of ingratitude becomes difficult. The Algerian judicial system inspired by the French model does not encourage the emergence of a strong and independent judicial personality with a well-known public reputation. The Council, therefore, remains an institution where the decision-making process is dictated by the collegiality, unanimity and coherence of the members guaranteed by the political nomination.

\section{Controversies around members of the Constitutional Council}

The appointment of members as such has not been controversial. However, certain questions emerged in the Algerian public debate concerning the members of the Constitutional Council.

Firstly, politicians who are appointed Chairman of the Council are sometimes challenged. It is hardly understandable for a party of observers to appoint former ministers close to the President of the Republic to preside the Constitutional Council; especially when these personalities do not necessarily have the technical capacities to judge the constitutionality of the laws, and are equipped with a preponderant voice in case of equality of the votes.

Secondly, the members of the Constitutional Council elected from among the members of the legislature are hardly detached from their political affiliation. In some cases, these members continue to have activist activity while serving as Council members.

For example, a controversy arose during the 2014 presidential elections around a member of the Constitutional Council who attended a meeting of President Bouteflika. It should be remembered that the Constitutional Council has the competence to validate candidates, to deal with electoral appeals and to declare results. The commitment of the member of the Board in question who attended a meeting of his political party prompted the reaction of the opposing candidates to the President of the Republic that consisted of challenging the impartiality of the Constitutional Council. 
It should be noted that the election of members to the Constitutional Council by the legislature is often a moment of controversy. In 2011, no rivalling candidate appeared in the Council of the Nation (Upper House) against the candidate of the RND Hocine Daoud who became part of the Constitutional Council. In 2013, opposition MPs from the People's National Assembly boycotted the election session of the member to be appointed to the Constitutional Council, Mr Graoui Hocine. The election of Judge Farida Laroussi by the magistrates of the Council of State in 2005 was challenged by her colleague Kamel Fenniche who would have won according to several reports. Judge Fenniche had denounced the irregularities of the ballot and the intervention of the President of the court in favor of the competitor. Finally, the Electoral Committee of the Council of State did not follow up on these allegations. Nevertheless, Judge Fenniche was finally elected in 2016 by his peers and installed in the Constitutional Council.

\section{The Constitutional Council in the middle of the Algerian political crisis}

Relatively, little attention was paid to the provisions governing the Constitutional Council in the debates on constitutional reforms. Between 2011 and 2016, political parties and Algerian civil society focused on the type of political regime, the rebalancing of powers and identity issues. The Constitutional Council remains an institution that has been misunderstood by a large number of players because of its hybrid character and discretion since 1989.

The constitutional revision of 2016 was the culmination of a long 5-year process of consultation and debate. It closed the debate, which brought together hundreds of associations and political parties. This revision modified for the third time the composition of the Constitutional Council. It seems therefore very unlikely that a new amendment will occur in the short term and will change the current provisions. That said, the Constitutional Council finds itself in the midst of the most important political crisis in the country.

The state of health of President Bouteflika is today the source of the first concern that animates the political scene. In his fourth mandate, he has delivered only one public speech since May 2012. Victim of multiple strokes, his ability to stand for re-election in 2014 was challenged by the political opposition. In spite of this state of health, the Constitutional Council validated the medical file of the candidate Bouteflika allowing him to run for a fourth term. Concerns were confirmed when Bouteflika 
was unable to hold any public meeting during the election campaign. Once reelected, his public appearances continue to show the deterioration of his state of health. Article 102 of the current contrition and 88 of the previous constitution give it to the Constitutional Council to declare the state of an impediment for medical reasons. According to the Constitution as by 2016, the Council meets by its own right and decides over this observation. No seizure or external action is required.

Since 2012, the Constitutional Council has never used this prerogative. This abstinence seriously undermined the Council's credibility, underlined by the fact that it is chaired by a former minister and close to the president. The members of the Constitutional Council are therefore perceived as political actors favoring the maintenance of the regime in place, to the detriment of the Constitution of which they are supposed to be the guardians.

This situation illustrates the limits of a politico-judicial model of constitutionality control. The appointment of the President of the Council by the President of the Republic also jeopardizes the balance of power and the impartial functioning of the Council.

\section{Conclusion}

The composition of the Algerian Constitutional Council enshrines its political and judicial nature. Although it differs from the French model by giving one-third of the seats to high court judges, it remains an institution of a more political than judicial character.

The decisive influence of the executive on the appointment of members is also an important feature of the Algerian Council. The President of the Republic shall appoint four members of the Council, including the President (who shall have a casting vote). This means that five out of 12 votes come from the executive. Two of the four members of the legislature are appointed by the Council of the Nation, one third of whom is appointed by the President of the Republic. Finally, the judges of the Supreme Court and the Council of State are appointed to office by the Council of the Magistracy, which is presided over by the President of the Republic.

As a result, the Constitutional Council reflects the Algerian political system, which suffers from a weak separation of powers and an imbalance for the benefit of the executive.

Tunisia and Morocco have chosen to depart from the French model since the Arab Spring and to move towards a constitutional court composed of judges, approaching the Kelsenian model. Algeria, Lebanon and 
Mauritania are the last three Arab countries still attached to the composition and the politico-judicial mandate of French tradition. It may take a new wave of political crises to challenge this model. 
